\title{
Experimental Investigation on The Effect of PolyVinyl Alcohol on Cement Fluid Loss in Oil Wells
}

\author{
Mohammed Jamal Awl \\ Petroleum Engineering Department \\ Faculty of Engineering | Koya University \\ Technical College of Engineering | Sulaimani Polytechnic University \\ Koya, Iraq \\ Mohammed.jamal@koyauniversity.org
}

\author{
Atta Sheakh Karim Abdulla \\ City Planning Engineering Department \\ Technical College of Engineering \\ Sulaimani Polytechnic University \\ Sulaimani, Iraq \\ atta.karim@spu.edu.iq \\ Nabil Adil Tayeb \\ Petroleum and Energy Engineering Department \\ Technical College of Engineering \\ Sulaimani Polytechnic University \\ Sulaimani, Iraq \\ nabil.talabani@spu.edu.ic
}

\begin{tabular}{l}
\hline Article Info \\
\hline Volume 5 - Issue 1 - \\
June 2020 \\
DOI: \\
10.24017/science.2020.1.9 \\
Article history: \\
Received: 12 April 2020 \\
Accepted: 26 May 2020 \\
\hline
\end{tabular}

Keywords:

FLAC,

PVA,

API Filtration Rate,

slurry,

cement,

HPHT Filter Press.

\begin{abstract}
This study presents the effect of PolyVinyl Alcohol Cement Fluid Loss Additive (PVA FLAC) on the API Filtration property of a cement slurry. In Cementing operations of oil wells, different type of fluid loss agents and chemicals are used based on the condition of the wells. PVA FLAC recently introduced in Kurdistan oil industry as loss agent additive to reduce the API Filtration Rate and fluid loss of the cement slurry. Four cementing formulations with different concentration of PVA FLAC additive prepared and their API filtration rates are measured. The results showed that when adding $1.94 \mathrm{gm}, 2.91 \mathrm{gm}$ and $3.88 \mathrm{gm}$ of PVA FLAC additive to the cement slurry, the API Filtration Rate reduced by \%17, \%29 and $\% 42$, respectively. The new concentration significantly reduced the rate of filtration when compared to using only $0.97 \mathrm{gm}$ of PVA FLAC additive.
\end{abstract}

Copyright (ㅇ 2020 Kurdistan Journal of Applied Research. All rights reserved.

\section{INTRODUCTION}

Cement is a material which used in oil and gas wells as well as in buildings and other constructions, it can cement materials together. It contains tricalcium silicate, dicalcium silicate, tricalcium aluminate and tetracalcium aluminoferrite. There are four types of cements 
based on cement standards: first is natural cement, the origin of this type is argillaceous, clay and lime rocks, also it is cheap. Second is Pozzolanic cement, the origin of this type is volcanic ash which is composed of aluminum, lime, calcium and iron. Third is Slag cement, the origin of this type comes from a mixture of hydrated lime, aluminum silicate and calcium silicate. Fourth is Portland cement, the origin of this type is limestone, and it consists of a mix of iron, alumina, silica and lime, it was used in buildings since mid of $19^{\text {th }}$ century in England. Different forms of current Portland cement are exist including fast setting and quick hardening which can be changed for white, colored and Pozzolanic cement [1].

The process of oil and gas wells cementing include injecting cement slurry from surface and passing through the casing and up to the annulus between the casing and the open hole. Any cement slurry consists of Portland cement (Cement class G, Cement class H, etc), water and some additives, the amount and type of additives differ from an application to another application [2].

For designing cement slurry, the laboratory is required for testing slurry at wellbore condition. These tests explain the effect of various additives on the cement properties such as thickening time, compressive strength, density, API fluid lose and rheological properties. In addition all parameters help the engineer in cementing design [3].

Dehydration of slurry occurred when water was released from the slurry, this process called filtration; also filtration rate can affect the setting of cement. The measurements in filtration test are volume of fluid loss in $(\mathrm{ml})$, filtration rate in $(\mathrm{ml} / 30 \mathrm{sec})$ and thickness of solid deposited on filter paper in (in). To reduce filtration rate, fluid loss additives should be added to the slurry, the additives such as: anionic synthetic polymer, non-ionic synthetic polymer, cationic polymer and cellulose derivative [4]. Recently PolyVinyl Alcohol is considered as the best type of Cement Fluid Loss Additive (FLAC) that is used by oil service companies including companies in Kurdistan Region. The objective of this study is to formulate four different slurry systems with different concentration of PolyVinyl Alcohol (PVA)FLAC additive and measure the API Filtration rate property for each slurry system and see the effect of the PVA FLAC additive efficiency on this property of the slurry system.

\section{LITERATURE REVIEW}

\subsection{Previous Study}

As explained in [5], which showed that the application of many additives for fluid lose control such as FLAC, also in most cases FLAC was observed to have noticeable effect on cement slurry. As demonstrated in [1], a mixture of nano particles with portland cement was studied, these nano particles can improve some properties of slurry such as fluid lose rate, density, thickening time and compressive strength. Also shown that the effect of nano barite on the cement slurry property. In addition, this nano barite reduces fluid loss, plugs pores of cement slurry and increase the compressive strength of cement. Because of barite had low cost and more availability, it is more used than other nano particles.

According to [6], the role of fluid loss control additives for cement slurry properties in oil and gas industry are explained and highlighted. Moreover, they explained that fluid loss control additives are not suitable for primary cementing job, because of high density of cement slurry and harmful for formation water invasion by fluid filtrate from the cement slurry.

As demonstrated in [7], the reasons for creating fluid loss at the time of pumping cement slurry were studied. These reasons were high cement slurry density, having gas migration, cement slurry dehydration and failure job of cementing or squeeze cementing. Furthermore, the researchers illustrated the dry surfactant such as Naphthalene Sulphonate Formaldehyde Condensate NSFC has been in use for cementing of oil and gas wells since 1960. Today this type of dispersant most commonly used to reduce viscosity of cement slurry and it makes effect on cement fluid loss. Another fluid loss control additive used in oil/gas wells is called acrylamide/acrylic acid copolymers [8]. In their study a relationship between temperature and fluid loss is concluded. With increasing temperature the amount of fluid loss is also increased. Hence, under extreme condition (high temperature) more fluid loss control additive is needed for cementing jobs. As demonstrated in [9] Cellulose or Hydroxyl Ethel Cellulose (HEC) 
studied as a fluid lose control additive. This additive is acceptable environmentally and it can work in high temperature up to $280 \mathrm{~F}$. A detailed study [10] showed that the fluid loss control additives had not any effect on the fluid loss property of cement slurry after cementing operation, however it had effect on slurry before setting cement slurry, since cement after its initial setting point became hard enough to seas any unwanted flow of water from cement to the formation so no more fluid loss occurred. According to [11], during cementing operation, a thin filter cake had been created, this filter cake decrease the filtrate of cement slurry to the formations around the wellbore.

The infiltration rate of around $100 \mathrm{ml} / 30 \mathrm{~min}$ is considered as high and not acceptable for cement job [12]. Best case value for API fluid loss is in the range between 10 to $30 \mathrm{ml} / 30 \mathrm{~min}$, and depends on geometry of the well, design of cementing, fluid loss properties of drilling fluid and overbalance pressure.

\subsection{Cement Classes and Functions}

There are eight specified classes of Portland cement based on API standards that were used in oil well cementing operation:

CLASS A: It is type I cement in ASTM (American Society for Testing Materials). It can be used in oil and gas wells to depth of $1830 \mathrm{~m}$; this type does not have any special property. This class is ordinary sulphate resistance (OSR), means that no tricalcium aluminate $\left(\mathrm{C}_{3} \mathrm{~A}\right)$ restrictions.

CLASS B: It is type II in ASTM, It can be used in oil and gas wells to depth of $1830 \mathrm{~m}$; In addition. This class is moderate to high sulphate resistance (MSR) to (HSR), means that contain $\% 8$ to $\% 3$ tricalcium aluminate $\left(\mathrm{C}_{3} \mathrm{~A}\right)$

CLASS C: It is type III in ASTM, also in oil and gas wells can be used to depth of $1830 \mathrm{~m}$; In addition. This class may be ordinary, moderate or high sulphate resistance (OSR), (MSR) and (HSR), means that it can contain $\% 0, \% 8$ or $\% 3$ tricalcium aluminate $\left(\mathrm{C}_{3} \mathrm{~A}\right)$.

CLASS D: In oil and gas wells can be used from depth of $1830 \mathrm{~m}$ to $3050 \mathrm{~m}$ under high pressure and temperature. This class is moderate to high sulphate resistance (MSR) to (HSR), means that contain $\% 8$ to $\% 3$ tricalcium aluminate $\left(\mathrm{C}_{3} \mathrm{~A}\right)$.

CLASS E: In oil and gas wells can be used from depth of $3050 \mathrm{~m}$ to $4270 \mathrm{~m}$ under high pressure and temperature. This class is moderate to high sulphate resistance (MSR) to (HSR), means that contain $\% 8$ to $\% 3$ tricalcium aluminate $\left(\mathrm{C}_{3} \mathrm{~A}\right)$.

CLASS F: In oil and gas wells can be used from depth of $3050 \mathrm{~m}$ to $4880 \mathrm{~m}$ under very high pressure and temperature. This class is moderate to high sulphate resistance (MSR) to (HSR), means that contain $\% 8$ to $\% 3$ tricalcium aluminate $\left(\mathrm{C}_{3} \mathrm{~A}\right)$.

CLASS G + CLASS H: In oil and gas wells can be used to depth of $2440 \mathrm{~m}$, and used to extremely deep wells at temperature. However the particle sizes of class $G$ is smaller than class $\mathrm{H}$ This class is moderate to high sulphate resistance (MSR) to (HSR), means that contain $\% 8$ to $\% 3$ tricalcium aluminate $\left(\mathrm{C}_{3} \mathrm{~A}\right)[4]$.

Purposes of cementing operations or functions are to:

1. separate the oil and gas of a formation to pollute another formation,

2. support and protect the well casing,

3. eliminate and fill the borehole caving and fractures

4. provide suitable space for production tools and equipment.

5 . avoid casing from corrosion by water and any other fluids [13].

\subsection{Cement Fluid Loss Additives}

Cement Fluid Loss Additives is abbreviated as FLACs, are mixed with cement slurry for controlling unwanted water losses from the slurry while pumping slurry to the weak formations around the wellbore. There are three types of FLACs based on working mechanisms. First, PolyVinyl Alcohol PVA, it can fill the filter cake pores of cement and make bridge particles by adsorbing water drop between cement particles. This application of long chain FLACs decreased fluid loss and permeability of filter cake. PVA works in temperature below $38^{\circ} \mathrm{C}$, above this temperature it cannot be used as fluid loss control. In 
order to be used at temperature range from $38^{\circ} \mathrm{C}$ to $60^{\circ} \mathrm{C}$, dispersant should be added to the slurry due to higher solubility of dispersant and more anionic. Second, PolyEthylene Imine, it plugs the filter cake pores of cement and prevent water loss from the cement to the formations. Third, the Cellulose polymer which can bound huge amount of water and prevent water loss during the process of filtration [14].

\subsection{Cement Laboratory Properties}

Cement tests should be applied on representative samples of cement, mix water and additives that will supplied by the rig's cementing crew. The detailed of cement tests are illustrated in API 10A and B. these tests or cement properties consists of the following:

1. Thickening Time: is the time of remaining cement as a pumpable state under well condition. The pumpability (consistency) is measured in Burden unit of Consistency (BC). While $1 \mathrm{BC}$ is equivalent to $2080 \mathrm{gm}-\mathrm{cm}$ of torque, maximum consistency can be achieved in laboratory is $70 \mathrm{BC}$. Mixing time and displacement time should be added to the thickening time as a safety factor. The device for measuring this property called High Pressure High Temperature (HPHT) Consistometer, and the device capacity is $2500 \mathrm{psi}$ and $400^{\circ} \mathrm{F}$ [4].

2. Slurry Density: cement slurry applies hydrostatic pressure on the open hole formations. This property is important to avoid lost circulation, formation fracturing and gas kicks. The device which is used for measuring cement density called Pressurized Mud Balance [15].

3. Compressive Strength: this property needs to suspend the casing in place, support wellhead equipment and control the formation pressure effect on the cement. Minimum acceptable compressive strength after cement hardening is 500 psi before resuming any operation. The device is used for measuring this property known as Ultrasonic Cement Analyzer (UCA) [15].

4. Yield: is the number of slurry sacks per one cubic foot of water. One sack of cement contains 94 pounds [15].

5. Lost Circulation: is the lost volume of drilling fluid to the surface or cement slurry to the casing annulus, the slurry or drilling fluid is loosed due to fracture, cavernous and permeable formations [15].

6. Fluid Loss: is the volume of mix water that is released from the cement slurry. It can be determined by Standard API Filter Press device in room temperature and 100 psi pressure or by HPHT Filter Press device in the laboratory, the device capacity is 1000 psi [15]. This property is very important for determining cement quality in cementing design [1].

The Standard API Filter press used for measuring filtration rate and thickness of the solid residue deposited on the filter paper caused by the loss of mud or cement fluids. This device is shown in Figure 1 and consists of a mud or cement cell, pressure assembly and filtering device. Filter paper in the cell represents the wall of the well. 

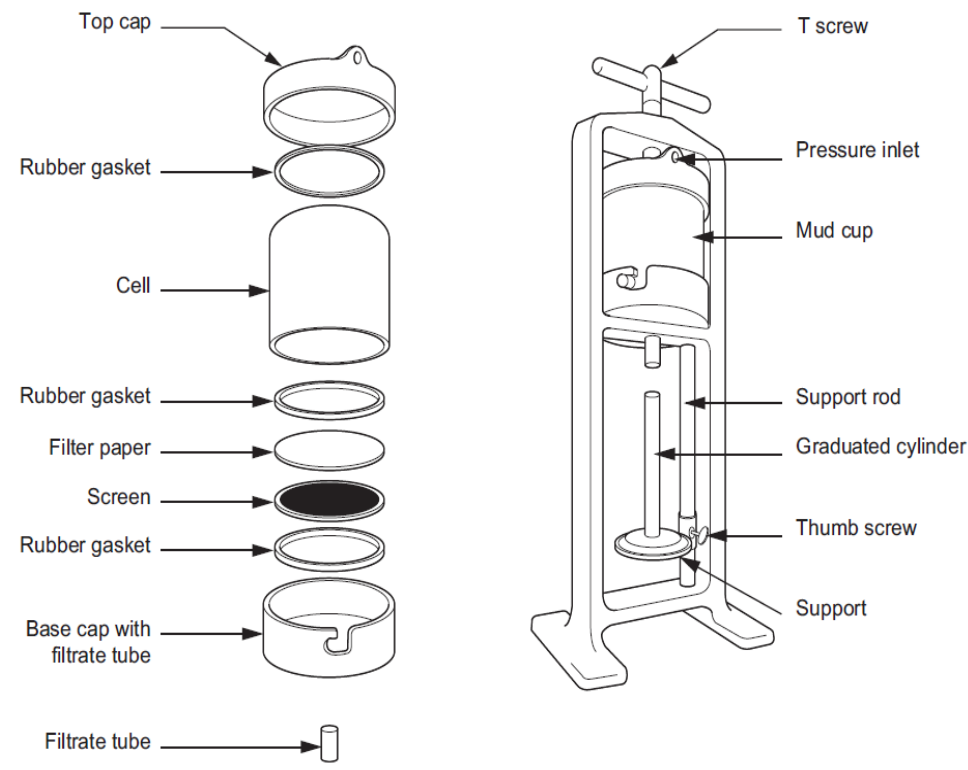

Figure 1: Standard API Filter press [3]

\section{METHODS AND MATERIALS}

\subsection{Overview Change this heading title to something like (Experimental Procedure)}

In order to achieve the objective of this study, High Pressure High Temperature Filtration experiment program was set up to study one of the properties of the cement with different concentration of PolyVinyl Alcohol Cement Fluid Loss Additive (PVA FLAC). The cement slurry was prepared and tested in Sprint Company for oil and gas service laboratory in Erbil. The Mixer and HPHT Filter press devices shown in Figure 2 and Figure 3.

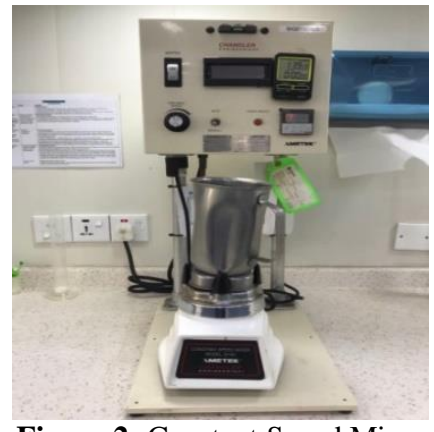

Figure 2: Constant Speed Mixer

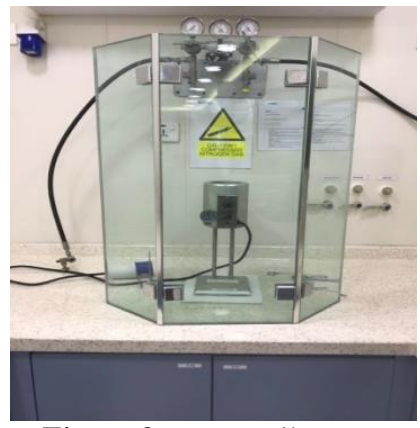

Figure 3: HPHT Filter press

Four slurries were tested to determine filtration rate according to API SPEC 10B, second edition, using (250-300) $\mathrm{ml}$ of cement under 1000 psi pressure using Nitrogen gas $\left(\mathrm{N}_{2}\right)$ for applying this pressure because $\mathrm{N}_{2}$ has no effect on cement property, the prepared cement slurries classified as low weight cement $\mathbf{L W}$ and consist of a combination of API cement class $\mathrm{G}$ and Cenosphere, both mixed with additives to provide the desired properties, see Table1. 
Table 1: Material components of cement slurry, descriptions and purposes

\begin{tabular}{lll}
\hline Materials & \multicolumn{1}{c}{$\begin{array}{c}\text { Chemical } \\
\text { origin }\end{array}$} & Purposes \\
\hline $\begin{array}{l}\text { Light Weight Cement } \\
\text { LW Cement) }\end{array}$ & $\begin{array}{l}\text { Cement class } \mathrm{G}+ \\
\text { Cenosphere }\end{array}$ & Having small density to the slurry \\
\hline Defoamer & Polypropylene glycol & $\begin{array}{l}\text { This additive used to prevent the foam in } \\
\text { the cement slurry }\end{array}$ \\
\hline PVA FLAC & Polymer & $\begin{array}{l}\text { This additive used to reduce the fluid loss } \\
\text { or filtration rate of the slurry. }\end{array}$ \\
\hline Dispersant & Sulphonate & $\begin{array}{l}\text { This additive used to reduce the viscosity of } \\
\text { the slurry. }\end{array}$ \\
\hline $\begin{array}{l}\text { Gas Migration } \\
\text { Control Additive }\end{array}$ & Polymer & $\begin{array}{l}\text { This additive used to prevent gas flow } \\
\text { through the slurry. }\end{array}$ \\
\hline $\begin{array}{l}\text { High Compressive } \\
\text { Strength }(\text { HCS })\end{array}$ & Micro-silica & $\begin{array}{l}\text { This additive used to increase the strength } \\
\text { of the slurry after hardening. }\end{array}$ \\
\hline Retarder & & $\begin{array}{l}\text { This additive used to increase the } \\
\text { thickening Time of the slurry. }\end{array}$ \\
\hline Water & lignosulphanate & \begin{tabular}{l} 
It is fresh water or mix water. \\
\hline
\end{tabular}
\end{tabular}

\subsection{Laboratory working Procedure:}

In general, the API filtration test procedure and sequence can be seen in the flow diagram Figure 4.

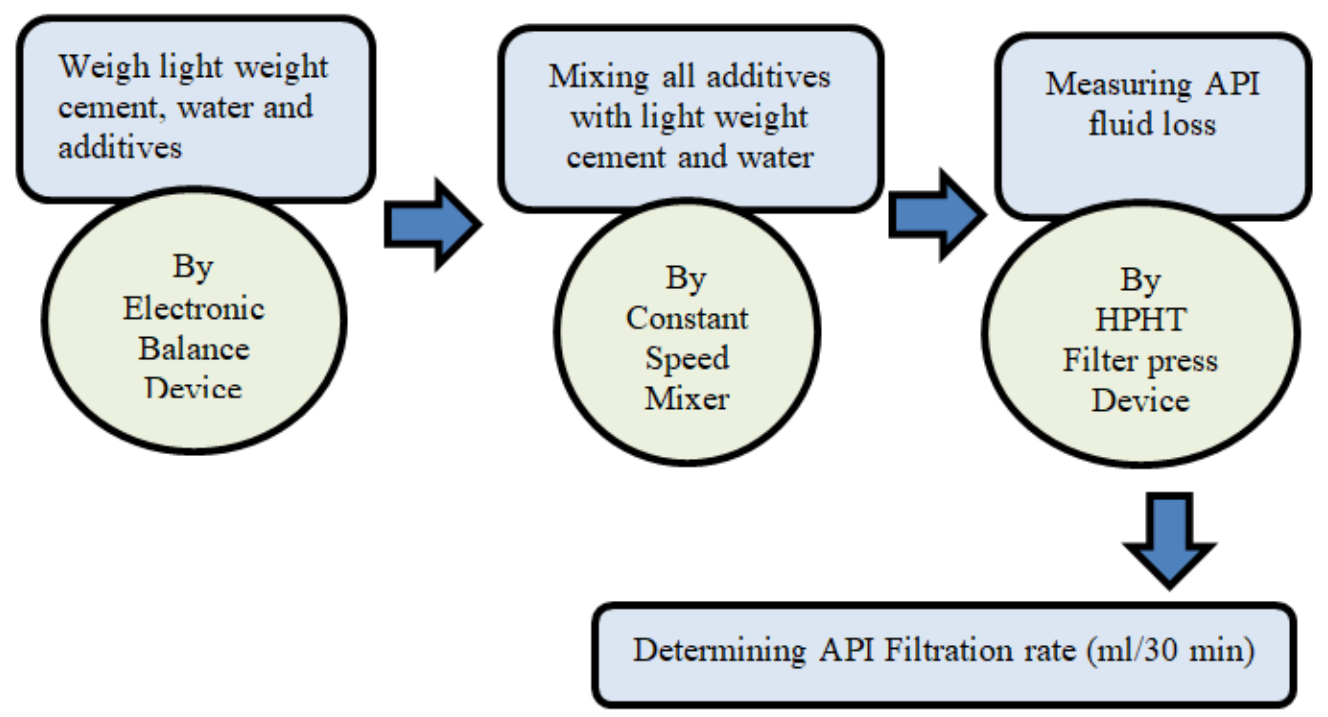

Figure 4: Flow chart for laboratory working procedure

The right volume and weigh water, LW Cement and Additives are determined and presented in Table 2 , but $0.20,0.40,0.60$, and 0.80 percent of PVA FLAC was used for Sample1, Sample2, Sample 3, and Sample 4 respectively which they stand for $0.97 \mathrm{gm}, 1.94 \mathrm{gm}, 2.91 \mathrm{gm}$, and 3.88 gm of PVA FLAC. 
Table 2: Additive Concentration

\begin{tabular}{llllll}
\hline $\begin{array}{l}\text { Sprint } \\
\text { Code/Type }\end{array}$ & Description & Unit & Concentration & $\begin{array}{l}\text { Laboratory } \\
\text { Concentartion }\end{array}$ & For 1 bbl \\
\hline LW Blend & LW Cement & $\mathrm{Ib} / \mathrm{bbl}$ & $1 \mathrm{sack}$ & $603.39 \mathrm{gm}$ & $352.49 \mathrm{lb}$ \\
\hline $\mathbf{C 0 1 1}$ & Defoamer & $\mathrm{Gps}^{*}$ & 0.02 & $0.86 \mathrm{ml}$ & $0.060 \mathrm{gal}$ \\
\hline $\mathbf{C 2 0 0}$ & Dispersant & $\% \mathrm{BWOC}^{* *}$ & 0.90 & $4.34 \mathrm{gm}$ & $2.538 \mathrm{lb}$ \\
\hline $\mathbf{C 3 0 3 N}$ & $\begin{array}{l}\text { Gas } \\
\text { Migration } \\
\text { Control } \\
\text { Additive }\end{array}$ & Gps * & 0.35 & $15.00 \mathrm{ml}$ & $1.050 \mathrm{gal}$ \\
\hline $\mathbf{C 3 5 1}$ & HCS agent & Gps* & 0.25 & $10.71 \mathrm{ml}$ & $0.750 \mathrm{gal}$ \\
\hline $\mathbf{C 1 0 2}$ & Retarder & $\% \mathrm{BWOC} * *$ & 0.05 & $0.24 \mathrm{gm}$ & 0.141 \\
\hline $\mathbf{H} \mathbf{0}$ & & & & $261.72 \mathrm{ml}$ & $0.436 \mathrm{bbl}$ \\
\hline
\end{tabular}

* Gps: Gallon per second

** \%BWOC: By weight percent of cement

The determined volume $261.72 \mathrm{ml}$ of water pureed in the cup of the Constant Speed Mixer runs in 4000 RPM for 15 second, at that time the additives added to the water and finally LW cement added, the water called mix water, mixed water with additives and LW cement called slurry, then the slurry mixed at 12000 RPM for 35 second then the Mixer put on Auto speed state for mixing the slurry. For filtration experiment the author added (250-300) $\mathrm{ml}$ of each cement slurry sample to the cell of HPHT Filter press under $(1000 \mathrm{psi})$ and $\left(95^{\circ} \mathrm{F}\right)$ for $(30$ minute), in his test we measure the volume of API fluid loss from the cement slurry and API filtration rate from this volume is determined. Similarly, the same procedure was followed to test the other for four samples with different concentration of Poly Vinyl Alcohol (PVA) FLAC.

\section{RESULTS}

Table 3 presents the results of API filtration rate of the cement slurry. Whilst Figure 4 demonstrates the relation between PVA FLAC concentration and API filtration rate for the four different formulation of cement slurry.

Table 3: API Fluid Loss Results

\begin{tabular}{llll}
\hline Sample Number & $\begin{array}{l}\text { PVA FLAC } \\
\text { Concentration \% }\end{array}$ & $\begin{array}{l}\text { PVA FLAC } \\
\text { Weight }(\mathbf{g m})\end{array}$ & $\begin{array}{l}\text { API } \\
\text { Filtration } \\
\text { rate }(\mathbf{m l} / \mathbf{3 0} \\
\text { min) }\end{array}$ \\
\hline Sample 1 & 0.20 & $0.97 \mathrm{gm}$ & 48 \\
\hline Sample 2 & 0.40 & $1.94 \mathrm{gm}$ & 40 \\
\hline Sample 3 & 0.60 & $2.91 \mathrm{gm}$ & 34 \\
\hline Sample 4 & 0.80 & $3.88 \mathrm{gm}$ & 28 \\
\hline
\end{tabular}




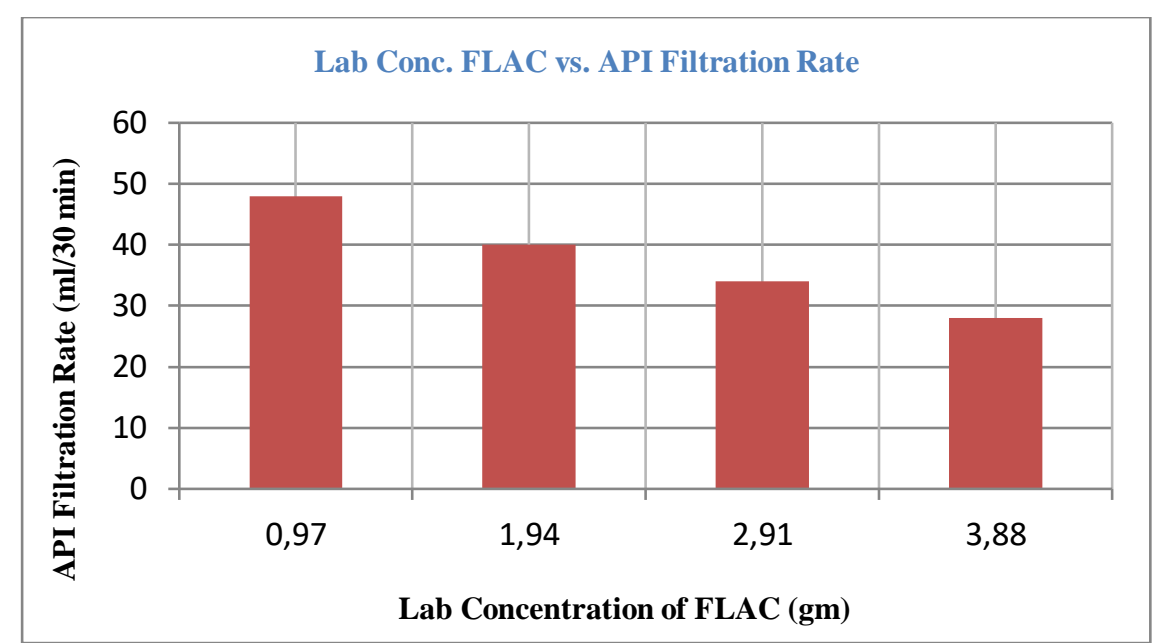

Figure 5: The standard deviation of Lab Concentrations of PVA FLAC with API Filtration Rate

\section{DISCUSSION}

Table 3 shows that increasing of the amount of added FLAC decreases the API Filtration rate which means it aids to prevent fluid loss from the slurry; this is due to that PVA FLAC has the following features:

. Because PVA FLAC is a polymer, it can increase the gel strength and viscosity of the slurry, also reduce free water and sedimentation.

. Having PVA FLAC additive in the slurry, can make more resistant to brines and acids.

. PVA FLAC additive does not retardation effect on the cement setting time.

. Having lower cost than other fluid loss control additives.

. Good compatibility with other cement additives.

. Reduce fluid loss during cementing within API standards.

If the water content in the slurry was lower than normal range, the following phenomena will be occurred:

1- Increase of slurry viscosity and density.

2- Decrease in permeability of the flowing slurry.

3- Sedimentation will be occurred.

4- $\quad$ Free fluid and fluid loss will be created.

Considering that all other additives are the same while slurry samples preparation, this research finds the obvious effect of PVA FLAC on the changes of filtration rate, Figure4 demonstrates the relation between Lab Concentrations of PVA FLAC additive and API Filtration Rate, this relation is inversely proportional. When the amount of PVA FLAC increased in the slurry, the API filtration rate decreased. This additive, polymer, can decrease the porosity of the slurry and reduce the uncontrolled fluid loss from the slurry.

Accordingly, PVA FLAC can reduce the API filtration rate, it can also plug the pores of the cement slurry and decrease the filter cake permeability of the cement [14].

The results of this study shows that using the optimum amount of PVA FLAC, provide the cement slurry which has good properties such as maximum strength after setting, also filling the annulus without any gap between cement particles from the casing shoe to the surface.

\section{CONCLUSION}

Inspections have been performed within in four cementing systems and determining the API Filtration Rate property for four different cement slurries. The findings by this study can be concluded as that the API Filtration rate property of the slurry can be decreased when increasing Poly Vinyl Alcohol (PVA) FLAC additive concentration to the slurry. The results show that when adding $1.94 \mathrm{gm}, 2.91 \mathrm{gm}$ and $3.88 \mathrm{gm}$ of PVA FLAC additive to the cement 
slurry, the API Filtration Rate were reduced by $\% 17, \% 29$ and $\% 42$ compare to $48 \mathrm{ml} / 30 \mathrm{~min}$ filtration rate from using $0.97 \mathrm{gm}$ of PVA FLAC additive respectively. The best sample was sample number 4 , due to having minimum filtration rate and optimum property of cement slurry.

\section{REFERENCE}

[1] A. Atashnezhad, T. Coryell, and G. Hareland, "Barite Nanoparticles Reduce the Cement Fluid Loss," SPE185114-MS, pp. 27-31, 2017.

[2] W. F. Prassl, "Drilling Engineering Curtin University of technology," 2017.

[3] Institute of Petroleum Engineering, "Drilling Engineering - Heriott Watt University,".

[4] H. Rabia, "Well Engineering \& Construction," p. 1 to 789, 2002.

[5] J. P. Pavlich and W. W. Wahl, "Field Results of Cementing Operations Using Slurries Containing a Fluid Loss Additive for Celnent.”SPE133,1962.

[6] J. F. Baret, "Why Cement Fluid Loss Additives Are Necessary,"SPE 17630, 1988

[7] D. T. Mueller and W. S. Bray, "Characterization of Surfactant-Enhanced Cement Fluid-Loss Additives," SPE 25442, 1993.

[8] L. F. Mckenzie and P. M. Mcelfresh, "Acrylamide/Acrylic Acid Copolymers for Cement Fluid Loss Control,'SPE 10623, 1982.

[9] B. Dao and P. Vijn, "Environmentally Acceptable Cement Fluid Loss Additive," SPE 74088, 2002.

[10] J. P. Haberman, M. Delestatlus, D. G. Hines, G. Daccord, and J. F. Baret, "Downhole Fluid-Loss Measurements From Drilling Fluid and Cement Slurries," JPT \& SPE 1992.

[11] J. Griffith and S. O Osisanya, "Effect of Drilling Fluid Filter Cake Thickness and Permeability on Cement Slurry Fluid Loss," Journal of Canadian Petroleum Technology, 1999.

[12] C. E. Bannister and V. M. Lawson, "Role of Cement Fluid Loss in Wellbore Completion," SPE 14433, 1985.

[13] N. J. Adam, "Drilling Engineering A complete Well Planning Approach," PennWell Publishing Company, Tulsa, Oklahoma, 1985.

[14] J. Plank, F. Dugonji, N. R. Lummer and D. Sadasiwan, "Comparative Study of the Working Mechanisms of Chemically Different Cement Fluid Loss Polymers,” SPE 121542, 2009.

[15] M. Ilyas, N. Sadiq, M. A. Mughal, H. Pardawalla, and S. M. Noor, "Improvement of cementing in deep wells," SPE/PAPG Annu. Tech. Conf. 2012, PATC 2012, pp. 155-172, 2012.

[16] API Recommended Practice 10B-2 Second Edition, April, 2013. 